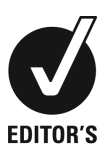

CHOICE
${ }^{1}$ Centro Hospitalar e Universitário de CoimbraHospital Geral, Coimbra, Portugal

${ }^{2}$ Centro Hospitalar e Universitario Coimbra, Coimbra, Portugal

\section{Correspondence to} Dr Andreia Fernandes, andreiafvf@gmail.com

Accepted 18 December 2014

\title{
A straightforward stroke? Maybe not: atypical presentation of type $A$ aortic dissection
}

\section{Andreia Fernandes, ${ }^{1}$ Francisca Caetano, ${ }^{2}$ M Carmo Cachulo, ${ }^{2}$ Lino Gonçalves ${ }^{2}$}

\section{DESCRIPTION}

A 57-year-old hypertensive man presented to the emergency department with right hemiparesis (blood pressure 145/90 $\mathrm{mm} \mathrm{Hg}$ ). An emergent head CT was performed confirming an ischaemic stroke (figure 1) and the patient underwent fibrinolysis. Within $12 \mathrm{~h}$ he developed shortness of

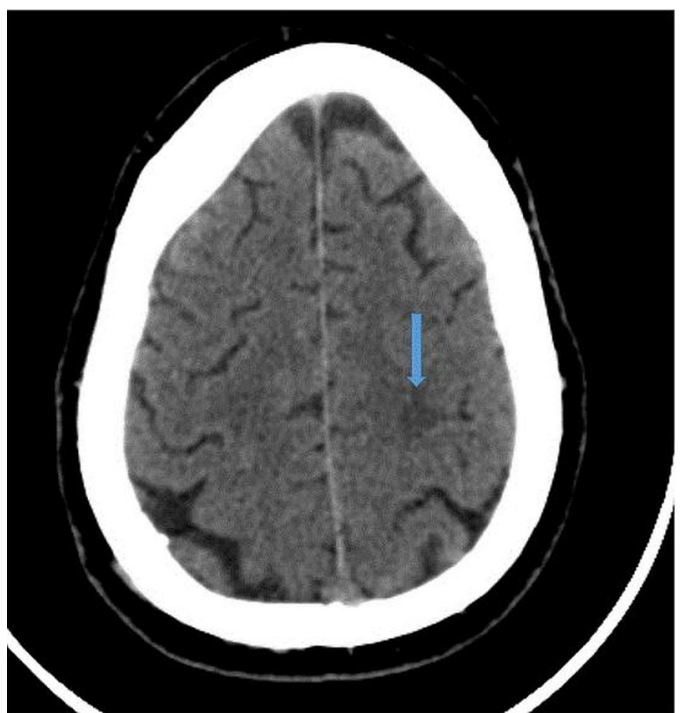

Figure 1 Head CT without contrast documenting an ischaemic posterior lesion (blue arrow). breath with hypoxia and inspiratory crackles on auscultation. Transthoracic echocardiogram showed an ascending aortic aneurysm with an aortic flap and severe aortic regurgitation (figure 2A, B). Stanford type A aortic dissection was confirmed by CT angiography (figure 3). The tear was localised in the proximal ascending aorta and the dissection propagated along the aortic arch to the right carotid (figure $3 \mathrm{~A}$ ) and descending thoracoabdominal aorta (figure $3 \mathrm{~B}, \mathrm{C}$ ), leading to acute renal (figure 3D) and hepatic failure. After clinical stabilisation the patient was submitted to surgical valvesparing root replacement. After 1 month of recovery he was discharged. On 24-month follow-up there was no aortic regurgitation and left ventricular function was normal. The follow-up CT (figure $4 \mathrm{~A}, \mathrm{~B})$ showed the entire dissection.

In the era of fast track fibrinolysis for acute stroke one has to bear in mind the differential diagnosis, which can easily be missed and lead to dismal outcomes. Aortic dissection is highly lethal with a mortality rate of $20 \%$ within $24 \mathrm{~h}$ without surgical treatment. ${ }^{1}$ Neurological deficits can occur in $18-30 \%$ of cases, most commonly cerebral ischaemia in $5-10 \% .^{2}$ Ascending dissections require emergency surgery ${ }^{3}$ and severe complications are likely if a patient is inadvertently treated with thrombolytic agents. Although submitted to fibrinolysis, our patient was successfully treated and survived.
To cite: Fernandes $A$, Caetano F, Cachulo MC, et al. BMJ Case Rep Published online: [please include Day Month Year] doi:10.1136/bcr-2014208491

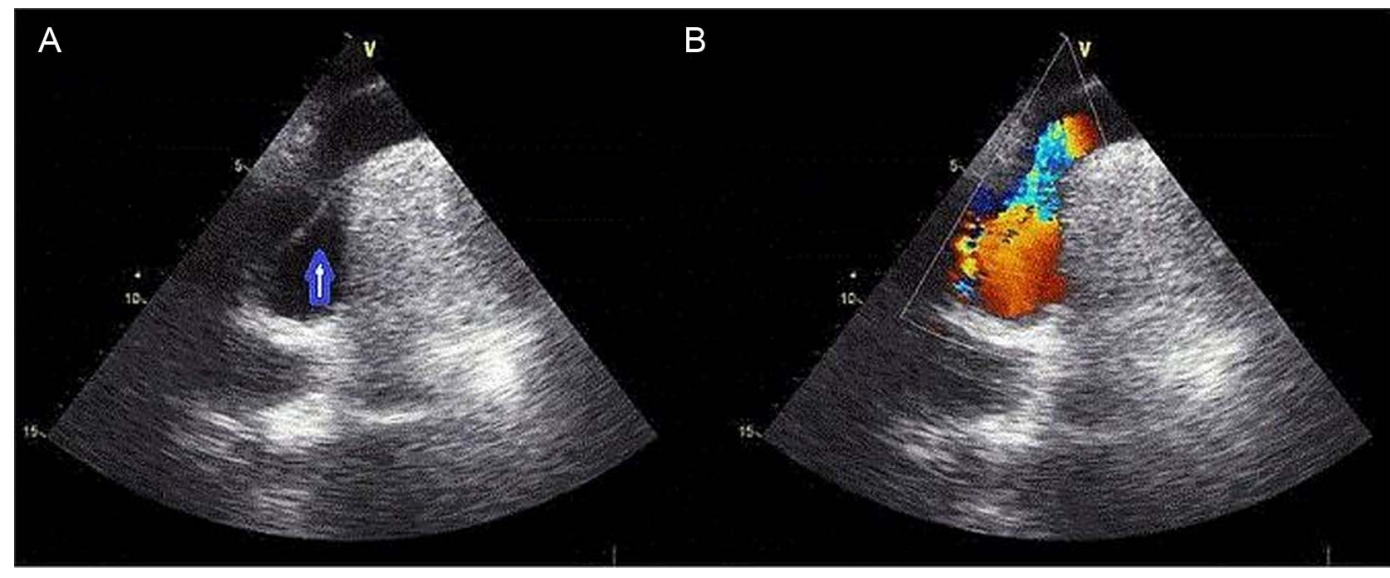

Figure 2 Transthoracic echocardiogram, suprasternal view: (A) ascending aortic aneurism with the dissection flap (blue arrow); (B) acceleration flow in the true lumen, which has almost collapsed. 


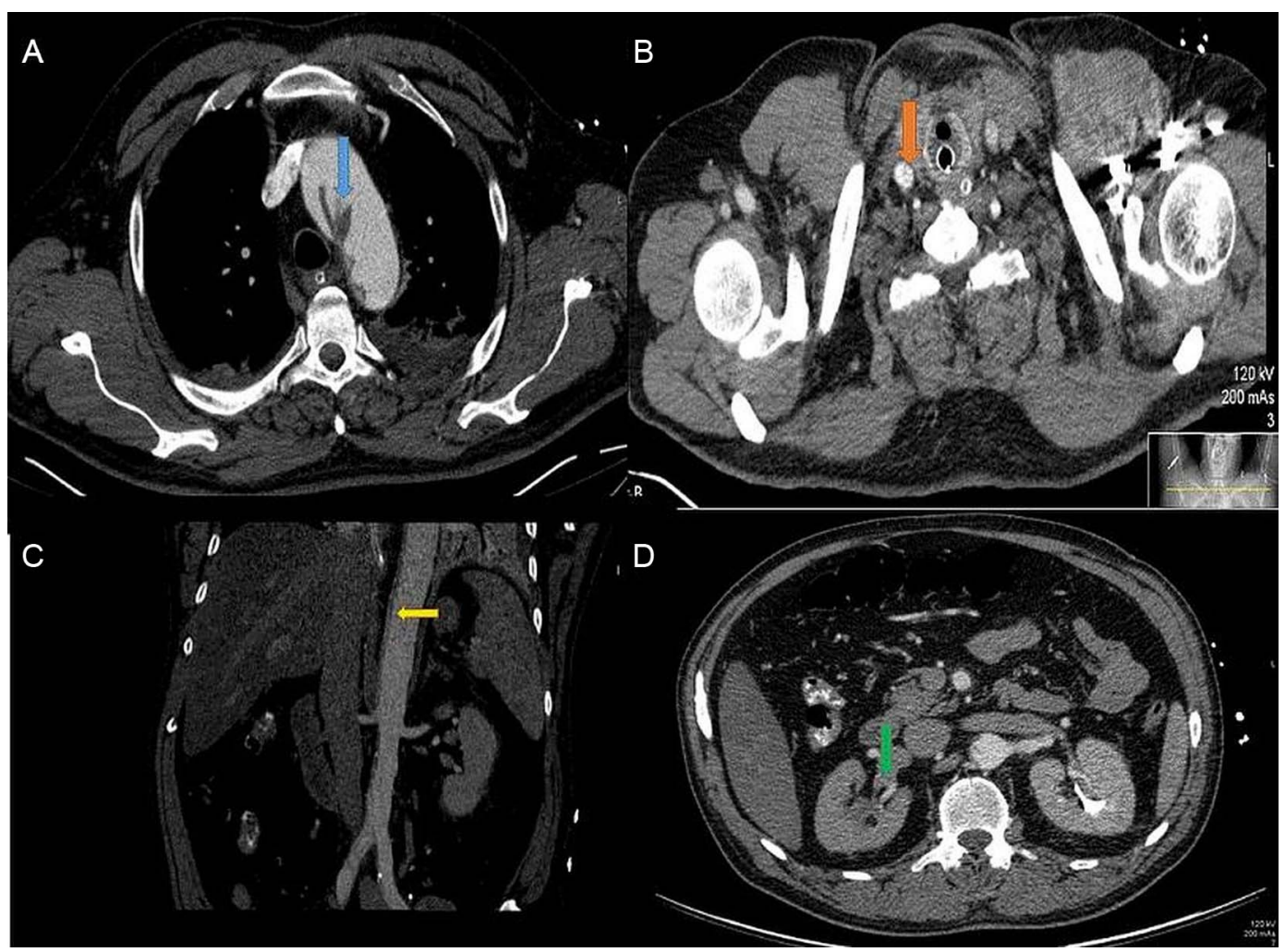

Figure 3 Contrast-enhancement CT: (A) tear/flap localised in the proximal ascending with the true lumen (blue arrow) almost totally collapsed; (B) dissection propagated along the right carotid (red arrow); (C) dissection propagated along the descending thoracoabdominal aorta with the true lumen collapsed (yellow arrow); (D) dissection localised in the abdominal aorta with the true lumen collapsed and the right kidney almost excluded (non contrasted, green arrow).

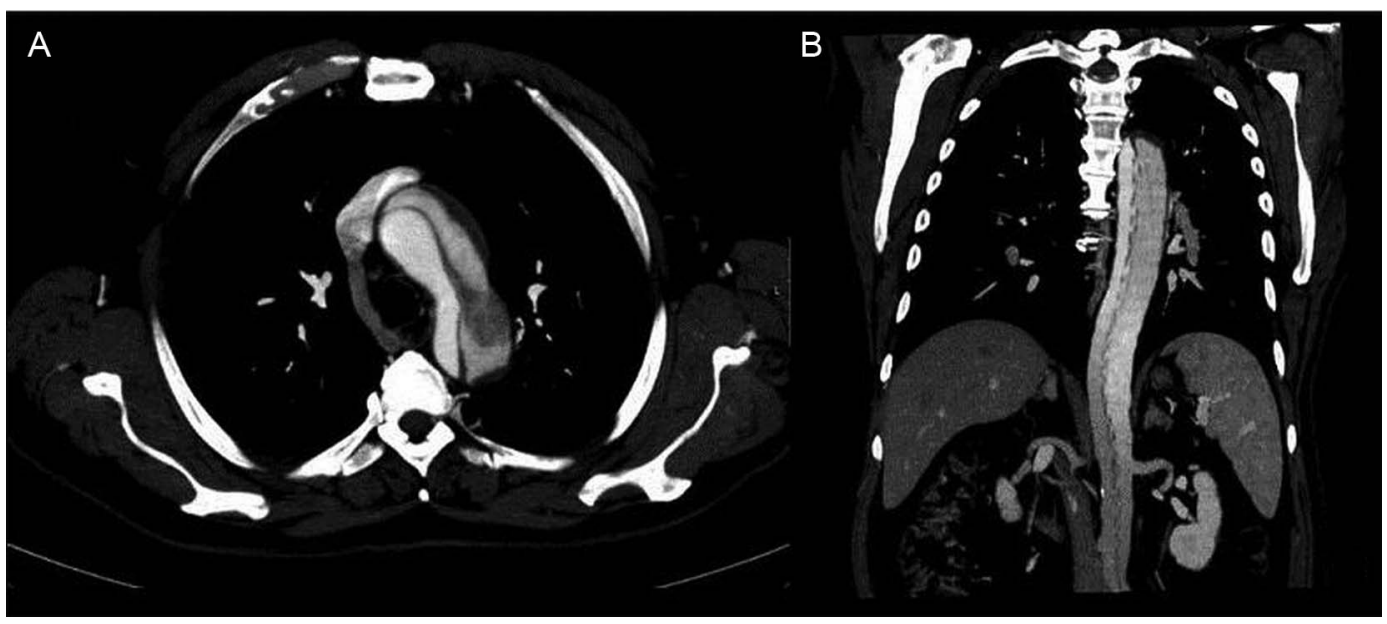

Figure 4 Contrast enhancement CT: (A) aortic flap in the aortic arch extending along the descending thoracoabdominal aorta with the false lumen permeable occupying about half of the aorta lumen; (B) the celiac trunk and the left renal artery arise from the false lumen. 
Learning points

- Stroke can be the clinical presentation of ascending aortic dissection. They share their most common risk factor: hypertension.

- Aortic dissection is a medical emergency with high mortality, markedly worsened by misguided fibrinolysis. Emergent aortic repair is lifesaving allowing 10 -year survival rates of $30-60 \%$.

- Before fibrinolysis in the context of stroke, one should consider bedside echocardiogram to assess the aortic root size or, if possible, perform a brain CT scan with synchronous vascular injection planning extending the image to the carotid arteries, the ascending aorta and the aortic arch.
Acknowledgements The authors thank Joana Trigo made the echocardiography evaluation, Catarina Oliveira made the angio-CT evaluation and Paula Mota reviewed the case.

Contributors All the above authors were involved in treatment of the patient. Competing interests None.

Patient consent Obtained.

Provenance and peer review Not commissioned; externally peer reviewed.

\section{REFERENCES}

1 Hagan PG, Nienaber CA, Isselbacher EM, et al. The international registry of acute aortic dissection (IRAD): new insights into an old disease. JAMA 2000;283:897-903.

2 Grupper M, Eran A, Shifrin A. Ischemic stroke, aortic dissection, and thrombolytic therapy — the importance of basic clinical skills. J Gen Intern Med 2007;22:1370-2.

3 Juang D, Braverman AC, Eagle K. Cardiology patient pages. Aortic dissection. Circulation 2008;118:e507-10.

Copyright 2015 BMJ Publishing Group. All rights reserved. For permission to reuse any of this content visit http://group.bmj.com/group/rights-licensing/permissions.

BMJ Case Report Fellows may re-use this article for personal use and teaching without any further permission.

Become a Fellow of BMJ Case Reports today and you can:

- Submit as many cases as you like

- Enjoy fast sympathetic peer review and rapid publication of accepted articles

- Access all the published articles

- Re-use any of the published material for personal use and teaching without further permission

For information on Institutional Fellowships contact consortiasales@bmjgroup.com

Visit casereports.bmj.com for more articles like this and to become a Fellow 